\title{
Mykola Khvyl'ovyy, Dmytro Dontsov, and the Transgressive Symbiosis of Communist and Nationalist Visions for a Revolutionary Ukrainian Literature
}

\author{
Trevor ERLACHER \\ PhD, Academic Advisor \\ Center for Russian, East European \& Eurasian Studies \\ University of Pittsburgh, PA (USA) \\ trevor.erlacher@pitt.edu
}

\begin{abstract}
Despite the tense geopolitical situation in interwar Eastern Europe, Ukrainian litterateurs at first elided the physical and ideological boundaries guarded by state authorities on either side of the Polish-Soviet border. Cultural leaders on the far right and far left, separated by a chasm of fear and loathing, nevertheless read and responded to one another's works. In some cases, representatives of the two sides shared common influences, beliefs, and aesthetic ideals, and even took the risk of signalling their admiration for the theories and creative accomplishments of sworn enemies in the opposing camp, favourably invoking "foreigners" to serve opposing agendas. Amid the relative openness, fluidity, and experimentalism that characterised the first (i.e. pre-Stalinist) half of the interwar period in Ukraine, few regarded nationalism and socialism, or even Bolshevism, as mutually exclusive concepts. Rather, there were synergies and points of contact between the two. Examining the public interaction of the Communist writer Mykola Khvyl'ovyy (1893-1933) and the nationalist literary critic Dmytro Dontsov (1883-1973), I argue that the Ukrainian cultural and political ferment of the 1920s was transgressive in two senses. Firstly, it cut across the political boundaries of party membership and citizenship that divided Ukrainians into Soviet and non-Soviet, socialist and nationalist. Secondly, it defied expectations of ideological purity and loyalty at a time of growing but not yet insurmountable hostility. The result was a symbiosis of right and left-wing agitation, in both Soviet Ukraine and south-eastern Poland, for a revolutionary, anticolonial, and modernist Ukrainian literature.
\end{abstract}

Keywords: Dmytro Dontsov, Mykola Khvyl’ovyy, nationalism, communism, Ukraine.

\section{Résumé}

Malgré les tensions géopolitiques au sein de l'Europe de l'Est de l'entre-deux-guerres, les écrivains ukrainiens ont initialement échappé aux frontières physiques et idéologiques, défendues par les autorités de l'État, des deux côtés de la frontière polono-soviétique. Séparés par un gouffre de peur et de dégoût, les leaders culturels d'extrême-droite et d'extrême-gauche ont néanmoins lu et réagi aux œuvres de leurs adversaires. Dans certains cas, les représentants des deux camps partageaient des influences, des croyances et des idéaux esthétiques communs. Ils ont parfois même pris le risque de manifester leur admiration pour les théories et les créations de leurs ennemis jurés du camp adverse, en invoquant les « étrangers » de manière favorable afin de revendiquer des programmes opposés. Dans le contexte de relative ouverture, fluidité et expérimentalisme ayant caractérisé la première moitié de l'entre-deux-guerres en Ukraine (c'est-à-dire la période pré-stalinienne), peu de personnes considéraient le nationalisme et le socialisme, voire même le bolchevisme, comme étant des concepts qui s'excluaient mutuellement. Il y avait plutôt des synergies et des points de contact entre les deux. En examinant les interactions publiques entre l'écrivain communiste Mykola Khvylovy (1893-1933) et le critique littéraire nationaliste Dmytro Dontsov (1883-1973), nous montrons que l'intense vie culturelle et politique dans l'Ukraine des années 1920 était transgressive dans deux sens. Premièrement, elle transcendait les frontières politiques liées à la citoyenneté et à l'affiliation à un parti qui divisaient les Ukrainiens entre Soviétiques et nonSoviétiques, socialistes et nationalistes. Deuxièmement, elle constitua un défi aux attentes de pureté idéologique et de loyauté à une époque où l'hostilité était grandissante mais pas encore insurmontable. Il en résulta un mélange d'agitation de droite et de gauche, tant en Ukraine soviétique que dans le sud-est de la Pologne, pour une littérature ukrainienne révolutionnaire, anticoloniale et moderniste.

Mots-clés : Dmytro Dontsov, Mykola Khvylovy, nationalisme, communisme, Ukraine. 


\section{Mykola Khvyl'ovyy, Dmytro Dontsov, and the Transgressive Symbiosis of Communist and Nationalist Visions for a Revolutionary Ukrainian Literature}

\section{Ukraine between Communism and Nationalism}

The interwar period looms large in contemporary Ukraine. Considering the parallels between then and now, the frequent invocation of this era in current political, cultural, and scholarly discourse makes sense. Today, as Ukrainians endure another bout of revolution and war, many seek their national "heroes and villains" amid the worst carnage of the last century (Marples 2007; Shkandrij 2020, 112-131). This includes the buoyant revolutions of 1917-1918; the catastrophic civil wars and anti-Jewish pogroms of 1918-1921; Ukrainisation and the cultural renaissance of the 1920s; the Famine of 1932-1933 and the Stalinist terror; the violent struggle of radicalised Ukrainian nationalists against the Second Polish Republic; and, bloodiest of all, World War II and the Holocaust. Given the ubiquity of memory politics and propaganda based on these events, and the ways in which they have been weaponised on both sides of the ongoing war between Russia and Ukraine, scholarly treatments of the interwar years can scarcely avoid being implicated in present-day political debates.

Broadly speaking, two camps take part in this conflict, which turns on the interpretation of Ukraine's fraught experience in the first half of the twentieth century. On one side, there is a Soviet-nostalgic, "pro-Russian" narrative that demonises Ukrainians as inherently fascist and anti-Semitic, presenting the ongoing war in the Donbas region as a sequel to the Red Army's victorious struggle against Nazi Germany (Osipian 2014, 109-140). This account is rooted in the myth of the Great Patriotic War and the imagined national community of Holy Rus' (the idealised spiritual and political union of the Soviet Union's East Slavic core, made up of Russians, Belarusians, and Ukrainians). The opposing antiSoviet and "Russophobic" view either denies the possibility of Ukrainian fascism or downplays its relevance to Ukraine's struggle for independence from Moscow, instead emphasising the record of Soviet and imperial Russian crimes against Ukrainians and the denial of their national and individual rights (Мартинець 
1949; Мірчук 1968). ${ }^{1}$ This narrative developed among the post-war Ukrainian diaspora of Europe and North America, many of whom were veterans of the nationalist movement in western Ukraine/south-eastern Poland, in particular the Organisation of Ukrainian Nationalists (OUN) and the Ukrainian Insurgent Army (UPA). ${ }^{2}$ Unsurprisingly, representatives of this camp tend to dismiss claims that the OUN and UPA were fascist organisations as rehashed Russian-Communist disinformation, rather praising them as the champions of a popular liberation struggle that lacked any totalitarian elements, and opposed Nazism as well as Stalinism (В'ятрович 2011; Квіт 2013). This stance gains a modicum of plausibility from the fact that Soviet propaganda incessantly deployed the accusation of fascism as a cudgel against its domestic and international enemies, whether they were militant nationalists, moderate liberals, or dissenting leftists, inevitably reducing the term to a hollow epithet. But Ukrainian nationalist commentators in the Cold War diaspora and independent Ukraine are also sceptical of non-Russian and otherwise nonpartisan historians and political scientists, who, arguing on the basis of careful research and engagement with the scholarly literature on fascism, show that the leadership of the OUN and UPA were guided by a fascist or protofascist ideology, collaborated with Nazi Germany, and perpetrated genocidal crimes against Poles and Jews during World War II (Himka 2011; Rudling 2011; Rossoliński-Liebe 2014 and 2015). Others scholars, staking out a sort of middle ground, refer to the OUN and associated groups as forms of "integral nationalism" -i.e. a right-wing-authoritarian ideology that subordinates individual rights, social progress, and democracy to the demands of the national interest. They argue that the nationalists of stateless nations cannot be fascists because fascism is (purportedly) a way of organising an already-existing state, whereas the OUN was engaged in a struggle to create a new state at the expense of several imperial powers (Armstrong 1955; Motyl 1980; Shkandrij 2015; Зайцев 2014). ${ }^{3}$

1 Volodymyr Martynets' and Petro Mirchuk were both veterans of the OUN, known for their role in creating Ukrainian nationalist historical myths during the Cold War. But post-war accounts of the OUN's enlightened beliefs and anti-Nazi heroism, produced by OUN members such as Martynets', Mirchuk, and others after World War II, should be taken with a grain of salt. Martynets', in particular, was a radically anti-Semitic racist who stopped just short of calling for outright genocide in 1938, considering it "easier to liquidate 44,000 Jews" by causing their "total and absolute isolation" from the Ukrainian people (Rudling 2012, 190).

2 The summation of this narrative is the 100-volume series Litopys UPA, a "chronicle" of the UPA's history, including various primary and secondary sources. Until 1991 it was partially funded by the CIA as part of the USA's ideological struggle against the Soviet Union and Communism (Litopys UPA, Ontario: Litopys UPA Publishing Company, 1978: https://litopysupa.com/book-series/litopys-upa-library/).

3 Alexander Motyl and John Armstrong brought Cold War ideological biases to their work on the history and content of interwar Ukrainian nationalism. By his own account, Motyl's scholarship was initially motivated by fervent opposition to the Soviet Union. Armstrong clearly sympathised with his subjects, the membership of the OUN and UPA, and recapitulated their own self-perception as anti-totalitarian freedom fighters in his work, which popularised the categorisation of the OUN and UPA as integral nationalists rather than fascists. 
Opponents of this interpretation regard the term "integral nationalism" as euphemistic, while its defenders argue that it has greater heuristic value as a concept than the more emotive and widely misused term "fascism." This controversy is rather semantic, however, as the historical record clearly shows that the OUN adhered to a far-right-wing nationalist ideology, embraced mass violence as a tool of political struggle, aligned itself with Nazism, participated in the Holocaust, and killed thousands of Poles and pro-Soviet Ukrainians. Overshadowing the increasingly stale and unproductive debate surrounding political labels and definitions, the legacy of interwar Ukrainian nationalists has become a flashpoint in the current political struggles over Ukraine, with one faction glorifying OUN and UPA leaders such as Stepan Bandera, while the other condemns them as fascist war criminals.

However much the inhabitants of modern-day Ukraine have pulled together in the face of oligarchic oppression and Russian aggression since 2014, incompatible historical mythologies continue to divide public opinion, with significant variance in attitudes between the regions in the country's north and west and those in its south and east. ${ }^{4}$ But the assumption that this rift is static and can be projected back into time, to the origins of the Soviet Union, or even into the pre-revolutionary era, is based on an overly simplistic dichotomy: Galicia versus Donbas - "Banderites" versus "Sovoks." In fact, the boundaries between the formerly Habsburg and formerly Romanov lands, between Polish Ukraine and Soviet Ukraine, and between Ukrainian Nationalism and Ukrainian Communism, were quite permeable and fluid in the 1920s and 1930s. This was an era when hostility between the two principal forces of twentieth-century Ukrainian politics is often supposed to have been the most intense and insurmountable. Despite occupying ideological antipodes and despising one another, members of the OUN and related organisations found common ground with Soviet agents and the Communist Party of Western Ukraine (KPZU). Both camps claimed to champion the creation of a united Ukraine, albeit under the auspices of different and radically opposed regimes, and both claimed to be fighting against Poland's imperialism and oppression of national minorities. Timothy Snyder describes this marriage of convenience in the Polish-controlled yet majority-Ukrainian region of interwar Volhynia, later the site of the OUN (Bandera faction) and UPA's ethnic cleansing of Poles in 1943-1944:

The truce surprised no one. The [Communist] Party had used nationalist agitation from the very beginning. Its leaders spoke not only of national cultural rights,

4 This is not an endorsement of the hackneyed notion, a la Samuel Huntington, that Ukraine is a "cleft country" straddling the frontier between two hostile "civilisations." 
but also of national self-determination and even state independence. Its May Day marchers carried Ukrainian flags, sometimes to the exclusion of red banners, and chanted "Long live Ukraine, down with Poland!" Party members in Volhynia had a decided preference for the Ukrainian national anthem over the Internationale. Since the [KPZU] had been officially dissolved by Moscow, and the Communist Party of Poland no longer existed, local communists could make whatever alliances they wished. In the past they had made efforts to follow the party line on questions such as cooperation with nationalists, but in the end, they followed the inclination of local members. The OUN, for its part, had modelled its political education on that of the communists. It had penetrated the [KPZU], and had been infiltrated in its turn by the communists. Throughout the 1930s, the OUN had used the party's demonstrations as an occasion for its own work, joining for example in May Day demonstrations. In Volhynia, both groups promised social and national revolution. It was the communists who spoke of a "final solution" to national problems in Volhynia, meaning that the Poles would be destroyed as the political class (Snyder 2005, 144).

The entanglement of communists and nationalists occurred in other parts of interwar Poland and Soviet Ukraine, too, and not just among pragmatic activists and agitators, but also at the upper echelons of political and literary discourse. Despite the tense geopolitical situation in interwar Eastern Europe, Ukrainian litterateurs at first elided the physical and ideological boundaries guarded by state authorities on either side of the Polish-Soviet border. Cultural leaders on the far right and far left, separated by a chasm of fear and loathing, nevertheless read and responded to one another's works. In some cases, representatives of the two sides shared common influences, beliefs, and aesthetic ideals, and even took the risk of signalling their admiration for the theories and creative accomplishments of sworn enemies in the opposing camp, favourably invoking "foreigners" to serve opposing agendas. Amid the relative openness, fluidity, and experimentalism that characterised the first (i.e. pre-Stalinist) half of interwar Ukraine's history, few regarded nationalism and socialism, or even Bolshevism, as mutually exclusive concepts (Velychenko 2015; Palko 2016, 575). Later critics, writing in more ideologically ossified years, have interpreted this cross-pollination as “ambiguity," naivete, hypocrisy, or treachery, but contemporaries saw an openness to learn from the world beyond their own party or country as indispensable to personal growth and national progress in art and politics. Viewed in hindsight, from the vantage of the Stalin era, the Second World War, and the Cold War, Ukrainian integral nationalism and Soviet Communism seem like antithetical forces. However, these movements were just taking shape in the 1920s and were not yet certain what to make of one another. There were many synergies and points of contact between them. 
The Ukrainian cultural and political ferment of the 1920s was transgressive in two senses. Firstly, it cut across the political boundaries of party membership and citizenship that divided Ukrainians into Soviet and non-Soviet, socialist and nationalist. Secondly, it defied expectations of ideological purity and perfect loyalty prior to being superseded by a period of violent animosity between Communists and non-Communists, citizens of the Ukrainian Soviet Socialist Republic and those of Poland, and of increased authoritarianism and dogmatism in both. The result was a short-lived yet wide-ranging symbiosis of right and left-wing agitation for a revolutionary, anticolonial Ukrainian literature in both Soviet Ukraine and south-eastern Poland. Of course, the two sides espoused incompatible conceptions of revolution, and of the ideal social and political order to which it would give rise. Moreover, the "anticolonial" posturing by many Ukrainian nationalists harboured colonial (or re-colonial) ambitions that could only be realised at the expense of non-Ukrainian populations. Sometimes these populations constituted a plurality or majority in the regions and cities that would be included in a "greater Ukraine, from the Danube to the Caspian Sea," as Mykola Mikhnovs'kyy envisioned in his influential pamphlet, Independent Ukraine [Самостійна Україна] (Міхновський 1902). Later, OUN leaders and mapmakers were even more expansionist in their thinking, dreaming of a Ukrainian empire that would supplant the Russian/ Soviet one.

During the Cold War, in the era of decolonisation, the Anti-Bolshevik Bloc of Nations (ABN), a descendent of the OUN-Bandera led by Yaroslav Stets'ko, sided with the white settlers of Rodhesia and South Africa, and opposed desegregation in the US South. Dontsov himself considered imperialism inevitable; the goal was to become the conqueror rather than the conquered. According to him, permanent peace among nations was not just a fantasy, but an undesirable one since the highest achievements of the nation (hence of humanity) are realised through war and expansion. What's more, at numerous points in his career Dontsov rather welcomed Ukraine's colonisation by western powers, taking a rosy view of German designs on Eastern Europe from the First to the Second World War, regarding it as the kind of civilising, anti-Russian, and anti-Bolshevik influence that would bring Ukraine back into Europe, and thereby hasten its advancement (Донцов 1915 and 1938; Erlacher 2014; Golczewski 2010). Nevertheless, Ukrainian nationalists viewed themselves as victims of double, triple, or even quadruple colonialisms (Russian, Polish, German, and Jewish), and represented their cause as both liberationist and anti-imperial. In the 1920s, Ukrainians of all political orientations and citizenships were in dialogue with one another, responded to 
overlapping intellectual influences, and articulated related prescriptions to shared problems.

But how much did they really know about one another, given the circumstances? Quantifying the circulation of foreign publications in early Soviet Ukraine would require further research, but it is clear that authors and political journals with an anti-Soviet bent were present and openly cited in Kharkiv, the republic's capital. While the intensity and reach of state censorship in Soviet Ukraine expanded in subsequent decades, in the 1920s it was still possible to access even the most "politically incorrect" works smuggled from across the western border. The General Directorate for the Protection of State Secrets in the Press (Glavlit), the main Soviet body charged with censoring or banning foreign and domestic publications, was created in 1922, shortly after the formation of the USSR. It was not until the 1930s, however, that Glavlit's mandate and capacity to control the flow and production of printed materials grew to the levels for which subsequent Soviet history is notorious (Ermolaev 1997, 51-58). The reach of early Soviet censorship was particularly limited in the Ukrainian lands, which were crisscrossed by the USSR's porous international borders with Poland, Romania, and Czechoslovakia, and still contested on the geopolitical arena. With the threeyear war to defeat the "Petliurists" (supporters of Ukrainian independence) in recent memory, the consolidation and permanence of Soviet power remained an open question in 1920s Ukraine. Confined to their bases of support in Russophone urban areas, the Bolsheviks and the newly formed Soviet state suffered a dearth of the kind of educated, ideologically reliable Ukrainian speakers that would be needed to surveil and censor Ukrainian texts without simply destroying them (as their imperial Russian predecessors had done).

Though Ukrainisation was the official policy intended to bridge the gap between the Russian-speaking proletarian city and the Ukrainian-speaking peasant village, and to raise the latter to the civilisational level of the former, many state workers and teachers refused to learn and use Ukrainian, deeming it an inferior dialect, while the police and Communist Party hardliners suspected that existing cadres of specialists in Ukrainian studies were anti-Soviet and nationalistic (Pauly 2014, 248, 323). Early Soviet censors scrutinised Ukrainianlanguage publications less often and more superficially than those published in Russian, in part because they lacked the staff and skills necessary to do so, but also because the official line of the 1920s regarded "local nationalism" as a lesser danger than "Great Russian chauvinism" when it came to the goal of building Soviet Ukraine into a modern, socialist, and proletarian nation (Martin 2001, 
356-362). ${ }^{5}$ By projecting an attractive image of national flowering and freedom of expression to presumably discontented Ukrainians living across the border in Poland, Soviet policy sought to make the Ukrainian Soviet Socialist Republic into a "Piedmont" that could unify all majority-Ukrainian lands into a single state at the expense of Moscow's regional rivals (Ibid., 274-281). ${ }^{6}$ But this was a sword that could cut both ways, with Polish-controlled East Galicia playing the role of Piedmont and the Soviet Union as the oppressor of nations. The anti-Soviet truce between Józef Piłsudski, the Prometheist movement, and some Ukrainian nationalists (including Dmytro Dontsov) hoped to achieve as much. Recognising the threat, Soviet authorities harnessed Ukrainisation to shift the centre of gravity in Ukrainian cultural life eastward, toward the Soviet Union's Russian core and away from Polish, German, and Galician-Ukrainian influences.

In Kharkiv, which the Soviet regime viewed as more loyal and less nationalistic than Kyiv, and hence as a place where Ukrainisation could occur safely, Ukrainian literature underwent a state-sanctioned renaissance in 1920s. This privileged status was clear in 1930, when the GPU "uncovered" a fictitious network of antiSoviet, Ukrainian nationalist intellectuals -the so-called Union for the Liberation of Ukraine (SVU) - and launched the wave of repression that spelled the end of Ukrainisation.7 The GPU cracked down on imagined SVU "cells" operating in almost all of Soviet Ukraine's cities, but did not arrest the Ukrainisers of Kharkiv, which was also the site of the ensuing show trials (Pauly 2014, 12). Thus, compared to Soviet Ukraine's other regions and subsequent decades, the atmosphere surrounding the production and consumption of Ukrainian literature in 1920s Kharkiv was relatively liberal. If there were anywhere in the Soviet Union where one could openly engage with what was being written in the western Ukrainian city of Lviv, it was in the eastern Ukrainian city of Kharkiv. Similarly, Lviv's Ukrainian readers across the political spectrum followed interwar Soviet Ukraine's literary scene and press in closely, consuming imported pro-Communist publications such as Chervonyy Shlyakh [Red Path], Bil'shovyk Ukrayiny [The Bolshevik of Ukraine], Pluh [The Plough], and Hart [Tempering].

5 Terry Martin traces the reversal of this "greatest-danger principle" to 1933.

6 Dmytro Dontsov regarded Poland as more friend than foe to the cause of Ukrainian liberation because it was an enemy to Moscow and Bolshevism, the true existential threat to Ukraine.

7 Following the same script from the centre, the SVU trial coincided with an even harsher crackdown on another fictitious network of nationalists in Soviet Belarus, the so-called Union for the Liberation of Belarus (SVB), which was allegedly coordinating an anti-Soviet insurgency with the SVU and Poland's help (Rudling 2014, 293-298). 


\section{Ukraine between Dontsovism and Khvyl'ovism}

An illustrative case of the transgressive symbiosis of Lviv's integral nationalism and Kharkiv's national communism in the 1920s is the interaction between the Ukrainian nationalist literary critic Dmytro Dontsov (1883-1973) and the Ukrainian Communist writer Mykola Khvyl'ovyy (1893-1933). ${ }^{8}$ Others have noted the similarities between the two influential writers (Чугуєнко 1996; Рахманний 1984). Although Dontsov and Khvyl'ovyy were the leading figures of two inimical movements in interwar Ukrainian literature and politics, their biographies, ideas, influences, and mutual reception contain many parallels. They were born ten years apart; Dontsov in 1883 and Khvyl'ovyy in 1893. Both hailed from the Russian-Ukrainian borderlands of what is today eastern Ukraine. Dontsov grew up in the town of Melitopol', just north of the Sea of Azov, and Khvy'lovyy came from Trostyanets, a small town near Sumy and not far from Kharkiv. Their family life and education were Russophone and steeped in the problems and classics of imperial Russian culture (Shkandrij 2001, 227-228; Сосновський 1974, 62-78). Both had fathers and close family members who identified as Russians, not Ukrainians. Their Ukrainian identities flowed from a choice or conversion experience with life-altering consequences. At the time, this was a hazardous cultural and political commitment requiring sustained will power and courage, as well as adaptability.

The First World War and its revolutionary aftermath was their touchstone experience, but they lived these years quite differently. Dontsov was already a well-established publicist and Ukrainian Social Democrat by 1914. He took a pro-Central Powers stance, calling for "the complete separation of Ukraine from Russia" on the eve of the war, during which he worked for the German Foreign Office. He did not return to Kyiv until the Central Rada, under attack from Soviet Russia, had already declared its independence. Shortly after his arrival he took

8 For a biography of Dontsov, see Сосновський (1974), and Зайцев (2019). My forthcoming book, Ukrainian Nationalism in the Age of Extremes: An Intellectual Biography of Dmytro Dontsov (to be published by the Harvard Ukrainian Research Institute in 2020), engages the issues raised here as they pertain to Dontsov and Dontsovism in much greater detail. This article is based on research done for this book. Sources consulted include the published, republished, and sometimes bowdlerized writings of Dontsov, the contributors to the journals he edited or worked for, and his supporters and opponents worldwide, as well as the contents of various archival collections. Chief among these is the Dontsov Archive, held in the Polish National Library in Warsaw, which contains the personal and official papers and extensive correspondence of Dontsov and associated individuals and institutions up to 1939. Between 2014 and 2016 the Dmytro Dontsov Scientific-Ideological Center -a Ukrainian nationalist think tank based in Drohobych, Ukraine - published a ten-volume collection of Dontsov's works. Faithful to the first editions, the collection is valuable to researchers despite the agenda of its creators. The second large repository of Dontsov's papers is held in the Library and Archives of Canada (LAC) in Ottawa and consists of letters, notes, articles, immigration documents, and miscellany from his last thirty years. I have also consulted Ukraine's state archival collections dedicated to Dontsov's associates and organisations.

CONNEXE 5 | 2019 - Divided Memories, Shared Memories, Poland, Russia, Ukraine: History mirrored in Literature and Cinema 
part in the German-backed coup of Hetman Pavlo Skoropads'kyy and served the new conservative-monarchist regime as a diplomat and information minister. Following Skoropads'kyy's downfall in November 1918, Dontsov fled Dnipro Ukraine for East Galicia, never to return again. These events drove him away from the Marxist internationalist ideas of his youth in the Russian Empire, which he blamed for the failure of the Ukrainian Revolution and the rise of Bolshevism. Instead, he embraced the fascist and "conservative revolutionary" zeitgeist that swept across interwar Central Europe. In 1926 he published his most influential work, Nationalism [Націоналізм], which laid the intellectual foundations for the OUN (Донцов 1926a). Dontsov was an early populariser and translator of Mussolini and after 1933, of Adolf Hitler, into Ukrainian life. His "worldview" (as he liked to call it) fits most of the definitions of generic fascism one encounters in the scholarly literature. ${ }^{9}$ Dontsov may have been a mere "literary fascist" who did not personally take part in violent actions, but he did align himself with the Third Reich, advocated the adoption of the same anti-Jewish policies in Ukraine, hailed Germany's Drang nach Osten, and wrote for the Reinhard Heydrich Institute in occupied Prague. Dontsov also embraced the "scientific" racialism and myth of Nordic supremacy lifted from his reading of Hitler, Hans Günther, and Eugen Fischer, arguing that the failed leadership of the UNR and pro-Soviet Ukrainians were not just politically, but also racially, inferior and ought to be purged from the national body along with Jews and Russians (Донцов 1944, 188-209; Erlacher 2017, chapter 5). Dontsov excused even the greatest crimes of the Axis Powers as a natural and necessary reaction against Bolshevism. After the war, he immigrated to Canada, denied having ever been pro-Nazi, excised the offending passages from his republished works, and was accepted by Western authorities, despite several press scandals and investigations into his past, as a valuable weapon in the Cold War with unimpeachable anti-Communist credentials (Erlacher 2017, chapter 6).

Khvyl'ovyy's wartime experience pushed him in the opposite, pro-Soviet direction. He served in the Imperial Russian Army, radicalised, joined the Communist Party (Bolshevik) of Ukraine (CP(B)U), and took part in the Russian Civil War on the winning side. According to the reputation for militant Communism cultivated by Khvyl'ovyy, his milieu and his supposedly "autobiographical" fiction, he served as a Cheka officer during the first years of the revolution. His life and work have been an ideological battleground open to a multitude of interpretations.

9 Roger Griffin's definition of fascism as a generic phenomenon -i.e. "a political ideology whose mythic core in its various permutations is a palingenetic form of populist ultra-nationalism" - describes Dontsov's interwar belief system well, as do the definitions proposed by Robert Paxton, Stanley G. Payne. A.J. Gregor, Ernst Nolte, and Zeev Sternhell (Griffin 1991, 26). 
The Ukrainian diaspora has generally promoted Khvyl'ovyy as the central figure of the "executed renaissance" (Hryn 2004), according to which he was a brilliant writer destroyed by Russian Communist tyranny whose death was an act of protest and disillusionment, or the consequences of a "fatal ambivalence" (Shapoval and Olnyk 2011). Problems of interpretation are compounded by the paucity and unreliability of primary sources, many of which were created by the Soviet secret services with the intent of discrediting Khvyl'ovyy and "Khvylovism," the catchall Soviet term for anti-Soviet Ukrainian nationalism, especially in the realm of culture (Palko 2016, 586-587). Shortly after the creation of the Soviet Union, Khvyl'ovyy became a writer and published his first poetry collections. He was certainly an ardent Communist during the Civil War, a period that he experienced as invigorating, ascetic, romantic, and filled with messianic promise, but this gave way to depression and disappointment. The New Economic Policy (NEP) period struck Khvyl'ovyy as bureaucratic and trivial, a betrayal of the youthful militancy and higher ideals of the Revolution (Palko 2016, 584). He wrote experimental satires and psychodramas depicting infatuation, then disillusionment, with a revolution snuffed out by insipid bureaucrats and boorish, colonial-minded philistines. His iconoclastic, futurist posturing and modernist style earned the acclaim of Dontsov, who had settled in Lviv and assumed the role of editor of Literaturno-Naukovyy Vistnyk [Literary-Scientific Herald], the foremost nonSoviet Ukrainian journal. Dontsov disparaged most Soviet Ukrainian writers for their sentimentalism, imitation of "Muscovite" literary forms, and the foreign, Russian idea of Communism, but immediately recognised a kindred spirit in Khvyl'ovyy, despite his loyalty to the Communist Party and the Soviet state (Донцов 1923a, 352). Dontsov praised the dynamism, originality, ruthlessness, and fanatical devotion to ideals in Khvyl'ovyy's writing. Dontsov considered these to be the most admirable traits of Bolshevism, urging Ukrainian nationalists to emulate them but in opposition to Moscow. As early as 1923 Dontsov detected a tragic desire to escape westward in Khvyl'ovyy's texts, implying that it would eventually destroy the author.

The problem that both Dontsov and Khvylovyy were well aware of and outspoken about was the perceived "split personality" from which Ukrainians suffered thanks to their position as a colony of Russia and a servant of its ideals. Dontsov's phrase for their slavish imitation of Russian culture was "national hermaphroditism" (Донцов 1928). This disease of the mind caused an inferiority complex and held Ukrainian cultural and political life back. Ukraine's redemption, according to Dontsov, would take the form of a restoration of its “European" essence 
and the purging of the contaminants introduced by its Russian and Bolshevik conquerors. Khvyl'ovyy addressed the same problem in a series of controversial pamphlets between 1925-1928. Written in the context of debates about the goals, implementation, and results of Ukrainisation, Khvyl'ovyy's essays sparked the socalled Literary Discussion. "By which of the world's literatures should we set our course?” Khvyl'ovyy asked.

On no account by the Russian. This is definite and unconditional. Our political union must not be confused with literature. Ukrainian poetry must flee as quickly as possible from Russian literature and its styles (quoted from Shkandrij 2001, 226).

He argued that Ukrainians should find their own national path, taking their lessons in civilisation and modernity directly from its supposed source Europe- without Russian interference. Only by leaving the stifling embrace of its erstwhile colonial master could Ukraine foster a national culture worthy of international recognition and capable of elevating the Ukrainian masses. Even more scandalously, Khvyl'ovyy blamed Russian chauvinist attitudes within the CP(B)U for the slow progress of Ukrainisation (Хвильовий 1986, 225-233 and Palko 2016, 581- 585).

Dontsov had already been arguing for over a decade that all Russians, no matter how liberal or progressive they claimed to be, were Ukrainophobic imperialists at heart. He also viewed Europe and Russia as distinct and fundamentally incompatible civilisations, arguing that Ukraine was obliged to choose the west over the east if it wished to survive and grow. Dontsov and Khvyl'ovyy shared a concept of "Europe" as a civilisational ideal. They were indebted to the same nineteenthcentury Russian problematic, the Slavophile/Westernizer debate. Both took aim at Russian messianism - a mixture of nationalism and imperialism, mysticism and utopianism distilled to its essence in Dostoevsky's novels. They even used the same biological metaphor, speaking of the "bacilli" of (Russian) imperialism and its inherent toxicity for Europe (Shkandrij 2001, 230; Донцов 1921, 67). But they also bemoaned the west's utilitarianism, purposelessness, and decadence. They admired Oswald Spengler's work, The Decline of the West (1918), which was fashionable in 1920s Eastern Europe and the Soviet Union (Донцов 1926, 26; Хвильовий 1986, 43-44; Hundorova 2017, 341-343; Rosenthal 2002, 181182). Spengler also divided the world into distinct and competing civilisations, all of which inevitably grow old, decay, and die, making way for new cultures. $\mathrm{He}$ predicted the demise of the West and its likely replacement by Asiatic peoples, Russia in particular. According to Spengler, Europe's aggressive, "Faustian" nature had made its meteoric rise to global hegemony possible, but the West had 
expended its energy and fallen into a state of stagnation and decay. Dontsov and Khvylovyy both saw something of great value in Europe as it once existed, at the height of its glory (Kratochvil 1999). Khvyl'ovyy defined "Europe" as:

The experience of many ages. Not the Europe that Spengler announced was "in decline," not the one that is rotting and that we despise. It is the Europe of a grandiose civilisation, the Europe of Goethe, Darwin, Byron, Newton, Marx and so on and so forth (Хвильовий 1925, 42). ${ }^{10}$

Similarly, Dontsov wished to see the restoration of Ukrainians to their natural status as a European, Faustian nation. Both picked Germany as the model, but at different moments in German history: Dontsov was focused on modern Germany, and closely engaged with it in practice; Khvyl'ovyy admired the Sturm und Drang of the late eighteenth century, which had its own "Europe" - Shakespearean England (Hryn 2017, 376). Both Dontsov and Khvyl'ovyy criticised the preceding generation of Ukrainian activists and writers -the left-wing populist Ukrainophiles- as too weak-willed, slavish, provincial, and sentimental to lead the liberation of Ukraine. Drawing again on a Spenglerian framework, Dontsov condemned them as products of a "Buddhist" culture, which, unlike the Faustian, takes the peaceful and bucolic existence of the humble farmer as its ideal, and renounces violence, conquest, expansion, and radical change. Dontsov singled out Mykhaylo Drahomanov, Dmytro Antonovych, and Mykhaylo Hrushevs'kyy for particular censure, calling them apostles of Provençalism (a reference to the doomed localism of French Provence). By focusing on pan-Slavic federalism, local autonomy, and internationalism instead of a merciless struggle for national independence, such authors condemned the people they claimed to love to a state of oppression and colonisation (Донцов 1926, 134-148).

Khvyl'ovyy's term for the same phenomenon was Prosvita, the Ukrainian word for enlightenment and the name of the popular education societies that operated in western and central Ukraine in the late nineteenth and early twentieth centuries. "We conceive of Europe as a psychological category that thrusts humanity forward, out of Prosvita and onto the great highway of progress" (Ibid.). Khvyl'ovyy criticised Taras Shevchenko, Mykola Skovoroda, and Ivan Franko as quietists. Khvyl'ovyy's Prosvita and Dontsov's Provençalism was the ethnographic obsession of the Ukrainophile intelligentsia, and the literature of simple-hearted odes to rural life in Ukrainian poetry. Such irreverence exposed both to accusations of iconoclasm from within their own camps, but Dontsov and Khvyl'ovyy the problem as a simple dichotomy —either Ukraine or Little Russia,

10 Myroslav Shkandrij's translation. Originally published in 1925.

CONNEXE 5 | 2019 - Divided Memories, Shared Memories, Poland, Russia, Ukraine: History mirrored in Literature and Cinema 
either a nation or a colony - there was no third way.

Where they differed was in the ideology that offered the best way forward. For Dontsov, who had abandoned the Marxism of his youth, fascism and radical nationalism were the wave of the future, the remedy for Provençalism and the appropriate response to Bolshevism, which was merely Russian imperialism in a new form (Донцов 1923b). Khvyl’ovyy, by contrast, tried to reinterpret Spengler's civilisations in terms of class struggle. He conceded that Spengler and Dontsov, who was one of the main popularisers of Spenglerian ideas in Ukrainian discourse, were "fascist" thinkers, but he argued that even fascists and class enemies could be right about some things and should be taken seriously when they are (Хвильовий 1986, 43). In Khvyl'ovyy's Marxist reinterpretation of Spengler, the declining West becomes the bourgeoisie and capitalism, while the rising East is represented by the proletariat and socialism. According to Khvyl'ovyy, Ukraine was poised to lead what he called an "Asiatic Renaissance" that would liberate the world's colonies and simultaneously revitalise Europe's cultures and societies (Хвильовий 1925, 33-34). This was thanks to Ukraine's unique position as a European yet colonised nation on the frontier of two civilisations -Eurasia and the West.

Dontsov also articulated a kind of Ukrainian messianism, but in his view Ukraine would be a bulwark against Oriental despotism and the hordes of Muscovy, not the conduit of youthful, Asiatic dynamism into Europe. Moreover, he expected the West, and Germany in particular, to pave the way for Ukraine. He called Khvyl'ovyy's "Asiatic Renaissance" a chimera, especially in the Soviet context, writing that "for a renaissance the free competition of talents is needed, but where is this allowed by the official ideology?!" (Донцов 1926b). Still, Dontsov commended Khvyl'ovyy for his courage in the face of Bolshevik oppression. He diagnosed Khvyl'ovyy's restless discontent as a symptom of colonial schizophrenia or "pseudomorphism," comparing him to Nikolay Gogol' (Mykola Hohol'):

The spectre of insanity will visit [Khvyl'ovyy] just as it did [Gogol']. Both were tormented by corrosive doubts, seeking in vain for a synthesis of their feelings with the science of the East, pouring out their grief in satire. Both yearned for the virtues of the Middle Ages. Both wrote about their divided “I.” (Донцов 1925).

Nevertheless, Dontsov believed that something momentous was happening just beneath the surface across the border in Soviet Ukraine:

Our eyes are turned toward the East. Unfortunately, however, our press pays attention only to official expressions of life there... This is a great pity! For what is hidden on that shore is a hundred times more interesting that any Ukrainisation. We are witnessing a change in Ukrainian consciousness, a profound change, pregnant 
with incalculable consequences (Ibid.).

In 1925 Dontsov expressed hope that Khvyl'ovyy might finally be the one "to kill the prosvityanshchina in our heads from one side and the ideology of Messianism from the other," replacing both with a "blue-and-yellow ideology of violence, fanaticism and cruelty." Dontsov returned to the subject of Khvyl'ovyy and the Literary Discussion in April 1926, this time comparing the latter to Petr Chaadaev and wondering if Khvyl'ovyy would soon pen his own Apology of a Madman [Апология сумасшедшего], once the Russians inevitably decide to destroy him (Донцов 1926b).

Dontsov was delighted to see that his ideology of "active nationalism" was making inroads in Soviet Ukraine, citing Khvyl'ovyy as a case in point:

They begin to speak, not only among eastern Ukrainian emigres, but also (I emphasise with pleasure) in the home country about 'psychological Europe,'

and about:

The need to construct within oneself this spirt of Occidental civilisation [that is] natural to us (Донцов 1926c, 167).

As of early 1926, Dontsov's and Khvy'lovyy's vision of a de-Russified, (re)Europeanised, and genuinely Ukrainian culture seemed to be gaining ground. Khvyl'ovyy's vision of an anti-imperial yet antiprovincial national cultural revolution; his Europhilia and Russophobia; the tension between traditionalism and iconoclasm in his thinking; his idealism, elitism, romanticism, and moral nihilism; his voluntarist critique of economic determinism; his focus on the creative power of youthful rebellion and violence; and the content, tone and lexicon of his pamphlets - all betrayed the influence of Dontsov's writings, which were available in Kharkiv and Kyiv at the time, and which, according to Yurii Shevelov, Khvyl'ovyy read "diligently and gladly" (Хвильовий 1978, 55). Khvyl'ovyy was not alone: Mykola Zerov, the leading neoclassicist poet in Soviet Ukraine, also regarded Ukraine, in explicit contrast to Russia, as a nation built upon the foundations of European antiquity, thoroughly permeated with its values and features (Зеров 1990, 585).

Although their political allegiances were diametrically opposed, Dontsov and Khvyl'ovyy espoused similar philosophies of history. Both started from Marxist premises, but revised the classical account of historical materialism, which presents history as the unfolding of class struggles and economic changes as the structure upon which cultures, politics, and ideologies are built. Instead, Khvylovyy and Dontsov joined the pan-European "revolt against positivism," doubting that 
history progressed in a linear fashion according to knowable scientific laws. They both embraced a sort of voluntarism, placing irrational will power and idealism at the epicentre of historical change. Khvylovyy called this "Romantic vitaism," Dontsov called it the "ideology of force," and both saw it as the key to a successful Ukrainian revolution (Донцов 1925, 207). To this end, they both favoured the creation of historical and utopian myths that would motivate people to commit acts of great violence as well as creation, here drawing on Georges Sorel's influential 1908 work, Réflexions sur la violence. Thus, Dontsov and Khvylovyy shifted the focus to individual heroism, not mass movements, elitism, not massism, and individualism, not collectivism. Nevertheless, both promoted what Dontsov called amoral'nist' (amorality) - the notion that the ends justify the means and might is right, and Ukrainians should not feel constrained by ethical scruples in their struggle for liberation. One can see this, for example, in Khvyl'ovyy's quasiautobiographical work I am (Romance) [Я (Романтика)], which tells the story of young Cheka officer whose devotion to the cause of revolution is so fervent that he orders and carries out the execution of his own mother, who also represents the old values and sentiments that held pre-revolutionary Ukrainians back.

The affinities between Dontsov and Khvylovyy extended to the realm of literary aesthetics, where both promoted iconoclastic experimentation. Prior to World War I, Dontsov had embraced the turn toward European modernism represented by the Kyiv-based literary journal Ukrayins'ka khata [Ukrainian House], 1909-1914). Khvyl'ovyy resumed the same generational rebellion of Nietzschean aestheticism and elitism that Ukrayins'ka khata had initiated. His Soviet opponents even took to denouncing his ideas and writings as "khata-like Europeanism" and "khatyanstvo" in reference to the journal (Ilnytzkyj 1991, 259). Dontsov favoured expressionism, futurism, neoclassicism, and impressionism over the "photographic realism" of nineteenth-century writing, with its focus on rural themes, the beauty of the natural world, sentimentalism, passivity, folklore, and social commentary. Apart from Taras Shevchenko, Lesya Ukrayinka and Mykola Khvyl'ovyy were the only two Ukrainian writers whom Dontsov openly admired in the 1920s. Inspirational stories of violent struggle, themes of national historical greatness, and heroic individual protagonists were needed, Dontsov thought. This neoromantic myth-making ought to be combined with high style. Khvyl'ovyy adopted similar positions as the leader of the Free Academy of Ukrainian Proletarian Literature (VAPLITE), advocating the production of literature of the highest quality and the cultivation of a literary elite, as opposed to the so-called "massism" of the proletarian and peasant writing clubs Pluh and 
Hart, of literature by and for the toiling classes. Writing on the subject of "art for art's sake," the dictum of modernism, Khvyl'ovyy sounded remarkably similar to Dontsov:

I attribute to the representatives of our modernistic Europe an enormous civic meaning because I look at things not from the syrupy-sweet principles of populism which retard national development but from a deep understanding of the national question (quoted from Ilnytzkyj 1991, 260).

As Ilnytzkyi argues, "instead of serving the narod (common people)," Khvyl'ovyy saw himself as "a servant of the national culture," even if the common people were incapable of appreciating it (Ibid., 261). For Dontsov it was a small step from this cultural elitism to an antiegalitarian political vision of hierarchies, dogmas, and castes.

Stalin's intervention in the Literary Discussion to rebuke Khvyl'ovyy and Oleksandr Shums'kyy, the main advocate of Ukrainisation in the $\mathrm{CP}(\mathrm{B}) \mathrm{U}$, as national deviationists was the beginning of the end for the Ukrainian cultural "renaissance." Shums'kyy turned on Khvyl'ovyy, accusing him of "zoological nationalism" and citing as proof the fascist Dontsov's praise of Khvyl'ovyy in Literaturno-Naukovyy Vistnyk (Mace 1983, 110). Khvyl'ovyy defended himself from accusations of being under Dontsov's influence, going so far as to threaten the latter with a violent death, even while admitting that he was "the most intelligent and consistent of the Ukrainian fascists." "When it becomes necessary and the possibilities are there, rest assured we will dispatch not only Mr. Dontsov to 'Dukhonin's General Staff'; but we will also know how to respect intelligent foes” (Хвильовий 1986, 174).

The reference is to General Dukhonin, the last commander of the Imperial Russian Army, whom Bolshevik soldiers killed and mutilated. Khvyl'ovyy insinuates that Dontsov and his ilk will meet a similar fate. And yet, Khvyl'ovyy repeatedly invoked the Literaturno-Naukovyy Vistnyk editor with approval:

Literature is the looking glass in which the rhythm of the national soul trembles, [says Dontsov and with complete justification... Here we agree with Mr. Dontsov]:

"We will not hand the country over to petty-bourgeois fools and egoists."

Khvyl'ovyy even invoked Dontsov's diagnosis of the Soviet Union's internal problems:

We are witnessing a serious moment - the moment at which, [to use Mr. Dontsov's words], 'the October psyche is beginning to break down,' [when, also in his words], 'a demobilisation of the revolutionary spirit is commencing along the entire front (Хвильовий 1986, 173, 197, 205). 
But Khvyl'ovyy was also determined to salvage his name and status within the Party. He began to hail Moscow and Russian culture, joining attacks against his erstwhile supporters in the Literary Discussion, such as O. Vlyz'ko, whom he rebuked for praising Hetman Ivan Mazepa and slandering Peter the Great. During these years, Yurii Shevelov notes, Khvyl'ovyy found a bevy of sins against the state and Marxism-Leninism in the writings of the new generation that once admired him:

Anti-Russianism, Trotskyism, nationalism, pro-Americanism,... provincialism, i.e. kulakism, idealism, kulak propaganda, the bourgeois idealism of Spengler, Dontsov, and 'other ideologues of fascism,' following in the footsteps of Dontsov, Petlyura, and Yefremov and the ideology of winded 'Ukrainisation' (Хвильовий 1978, 40; Рахманний 1984, 17).

Nevertheless, Khvyl'ovyy was forced to publicly renounce his errors in December 1926 and leave the ranks of VAPLITE, which was also shut down as the tide turned against Ukrainisation. Khvyl'ovyy chose to remain in Kharkiv and try to restore his reputation as a Communist writer, but his new publications flopped. Observing the young writer's fall from the Party's grace, Dontsov wrote that:

The whole of Soviet literature in Ukraine is the best proof that creative literature can grow only from one's own sensual and spiritual grounds; that cleft souls will not create new literature (Донцов 1928).

Once the Party had condemned "Khvyl'ovizm" and "Shums'kizm" as Dontsovinspired "national deviations," show trials of Ukrainisers and crackdowns on alleged anti-Soviet conspiracies began in the Ukrainian Soviet Socialist Republic. In the following decade, Dontsov's warnings that the Soviet regime would initiate the physical, not just cultural, destruction of the Ukrainian intelligentsia and peasantry were tragically validated. Collectivisation and the Famine-Terror of 1932-1933 coincided with an aggressive campaign against "local nationalism." Driven to despair by the situation in the country, Khvyl'ovyy committed suicide on May 13, 1933 (Carynnyk 2015). Dontsov presented Khvyl'ovyy's fate as proof that defiantly, authentically Ukrainian intellectuals and artists could not survive under Russian Communist rule:

The most terrible thing is the moral death that awaits everyone [in Soviet Ukraine] whom the conviction or feeling of self-respect will not allow to swear on every letter of the Leninist Koran. I did not think then [during the polemic with Khvyl'ovyy] that soon I would have such a tragic illustration of this assertion; that between physical and moral death, Khvyl'ovyy would choose the former as less terrible (Донцов 1933). 
Despite his failed efforts to reconcile the contradiction between Ukrainian national cultural striving on the one hand, and collaboration with Bolshevism on the other, Khvyl'ovyy's convictions and writings could lead only to his downfall:

It would be strange if such a smart and nimble journalistic and literary career as his did not mobilise those who gathered around the "centre of federal Philistinism" -the Party, Moscow - against Khvyl’ovyy... He preaches rebellion? But how dare he "sing of an abstract uprising, and idealise historical romance?" This means "to incite the petty-bourgeois element to active struggle against the dictatorship of the proletariat," the time for "chaos and natural force [stykhiya] is already finished!" The proletarian was the rebel, now he is "a conscious member of the organised collective, now he is a 'builder.'.. How dare he propagate 'the struggle of two cultures,' when 'national enmity is a relic of the old relations?" (Ibid., 92)

When Khvyl'ovyy finally realised that those who struggle, not for their own cause, but for the cause of a new empire, a new Moscow, are merely "hired gladiators" - that "Moscow, with its 'majority' [represented] the all-levelling herd as a principle, not only of political but also of spiritual life"- at that moment he killed himself. Nevertheless, Dontsov hailed Khvyl'ovyy's "final jest" as "a terrible mortal blow for the deceitful politics of Russia in Ukraine" (Ibid., 93-94). Dontsov's proteges, the nationalist poets Olena Teliha and Yevhen Malanyuk praised Khyl'ovyy as the embodiment of a national, voluntarist standard, celebrating his suicide as an act of defiance and sovereign will (Grabowicz 1998, 168). Nationalist critics who wanted to turn Khvyl'ovyy into an anti-Soviet martyr rejected the idea that he was a sincere and voluntary Communist and proletarian writer. In any event, his struggle to solve Ukraine's "national question" reflected a real struggle between "two Soviet republics and two distinct Communist Parties" (Palko 2016, 598). Now there could be no question of returning to the old Sovietophilia; selfrespecting Ukrainians, no matter their political ideology, would have to regard Bolshevism as the enemy. The Western Ukrainian Communist Party agreed, breaking with $\mathrm{CP}(\mathrm{B}) \mathrm{U}$ in protest of its attack on "Shums'kizm" and its betrayal of Ukrainisation.

Official Soviet discourse condemned Khvyl'ovyy's suicide, maligning him alongside Dontsov, the nationalist enemy who built a long career on anti-Soviet diatribes. Dontsov's flirtation with Soviet literature was also subversive in his West and émigré Ukrainian milieus, though he did not pay near the same price for expressing himself in print. His praise of Khvyl'ovyy, his Russian surname and education, the orthodox Marxism of his youth, his Russian Communist older brother, his open admiration for the brutal methods and fanaticism of Lenin and Stalin, and his call on Ukrainians to become more like their victorious oppressors 
(i.e. Russian Bolsheviks) also exposed him to accusations of ideological impurity and consorting with the enemy by fellow Ukrainian nationalists. ${ }^{11}$ Ultimately, the transgressive symbiosis of integral nationalist and Communist visions for an anticolonial, pro-European, and avant-garde Ukrainian culture was short-lived and harmful for individuals in both parties.

The consequences may have been worse for Soviet Ukrainian writers who dabbled in fascist themes than they were for Polish Ukrainian writers who took up Communist ideas in the late 1920s and early 1930s, but both faced repression at the hands of invading powers. The fates of Soviet Ukrainians accused of fascism or bourgeois nationalism - execution, suicide, and damnatio memoriae-proved that contacts with the other side were a dangerous proposition. Local western Ukrainian communists and nationalists alike faced persecution by the NKVD during the Soviet occupation of Galicia and Volhynia in 1939-1941 (Gross 2002, 234, 358). Acknowledging these commonalities of experience and worldview suggests that subsequent decades have overshadowed the experimentalism, openness, and nonconformity of Ukrainian cultural life in the 1920s, before the integral nationalists and the national communists, as illiberal descendants of the same revolution, had ceased to admit any shared ground and hardened into warring camps.

\section{Bibliographical references}

Armstrong, John. 1955. Ukrainian Nationalism, 1939-1945. New York: Columbia University Press.

Bercoff, Giovanna Brogi, Marko Pavlyshyn, and Serhii Plokhy (dir.). 2017. Ukraine and Europe: Encounters and Negotiations. Toronto: University of Toronto Press.

Carynnyk, Marco. 2015. “A Bit of Bloodstained Batting. Kharkiv, Satruday, 13 May 1933.” Krytyka.com. https://krytyka.com/en/articles/bit-blood-stained-batting-kharkiv-saturday-13-may-1933

Donzow, Dmytro. 1915. Die ukrainische Staatsidee und der Krieg gegen Russland. Berlin: C. Kroll.

Erlacher, Trevor. 2014. "The Birth of Ukrainian 'Active Nationalism': Dmytro Dontsov and Heterodox Marxism before World War I, 1883-1914.” Modern Intellectual History 11 (3): 519-548.

Erlacher, Trevor. 2017. "The Furies of Nationalism: Dmytro Dontsov, the Ukrainian Idea, and Europe's Twentieth Century." PhD diss., University of North Carolina at Chapel Hill.

Ermolaev, Herman. 1997. Censorship in Soviet Literature, 1917-1991. Lanham: Rowman \& Littlefield.

11 Vyacheslav Lypyns'kyy, for example, dismissed him as a cowardly and opportunistic imitator of revolutionary Russian courage and ideas -a "Moskal" in Ukrainian disguise (Липинський 1926, xxii-xxiii). Varieties of this critique dogged Dontsov throughout his life.

CONNEXE 5 | 2019 - Divided Memories, Shared Memories, Poland, Russia, Ukraine: History mirrored in Literature and Cinema 
Golczewski, Frank. 2010. Deutsche und Ukrainer, 1914-1939. Paderborn: Schöningh.

Grabowicz, George G. 1998. "Symbolic Autobiography in the Prose of Mykola Khvyl'ovyi (Some Prleiminary Observations)." Harvard Ukrainian Studies 22, Cultures and Nations of Central and Eastern Europe: 165-180.

Griffin, Roger. 1991. The Nature of Fascism. London and New York: Routledge.

Gross, Jan. 2002. Revolution from Abroad: The Soviet Conquest of Western Ukraine and Western Belorussia. Princeton: Princeton University Press.

Himka, John-Paul. 2011. "Debates in Ukraine over Nationalist Involvement in the Holocaust, 2004-2008.” Nationalities Papers 39 (3): 353-370.

Hryn, Halyna. 2004-2005. "The Executed Renaissance Paradigm Revisited." Harvard Ukrainian Studies 27 (1/4): 67-69.

Hryn, Halyna. 2017. "Literaturnyi iarmarok: Mediation between Nativist Tradition and Western Culture." In Ukraine and Europe: Cultural Encounters and Negotiations, edited by Giovanna Brogi Bercoff, Marko Pavlyshyn, and Serhii Plokhy, 374-389. Toronto: University of Toronto Press.

Khvyl'ovyi, Mykola. 1986. The Cultural Renaissance in Ukraine: Polemical Pamphlets, 19251926. Translated by M. Shkandrij. Edmonton: Canadian Institute of Ukrainian Studies, University of Alberta.

Kratochvil, Alexander.1999. Mykola Chvylovyi. Eine Studie zu Leben und Werk. Munich: Slavistische Beitrage.

Hundorova, Tamara. 2017. "The Train to Europe: Berlin as a Topos of Modernity in Ukrainian Literature in the 1920s." In Ukraine and Europe: Cultural Encounters and Negotiations, edited by Giovanna Brogi Bercoff, Marko Pavlyshyn, and Serhii Plokhy, 340-360. Toronto: University of Toronto Press.

Ilnytzkyj, Oleh. 1991. "The Modernist Ideology and Mykola Khvyl'ovyi." Harvard Ukrainian Studies 15 (3/4): 257-262.

Mace, James E. 1983. Communism and the Dilemmas of National Liberation: National Communism in Soviet Ukraine, 1918-1933. Cambridge: Harvard Ukrainian Research Institute.

Marples, David R. 2007. Heroes and Villains: Creating National History in Contemporary Ukraine. Budapest: Central European University Press.

Martin, Terry. 2001. The Affirmative Action Empire: Nations and Nationalism in the Soviet Union, 1923-1939. Ithaca and London: Cornell University Press.

Motyl, Alexander. 1980. The Turn to the Right: The Ideological Origins and Development of Ukrainian Nationalism, 1919-1929. Boulder, CO: East European Monographs.

Osipian, Alexander. 2014. "Historical Myths, Enemy Images and Regional Identity in the Donbass Insurgency (Spring 2014).” Journal of Soviet and Post-Soviet Politics and Society 1 (1): 109-140.

Palko, Olena. 2014. "Ukrainian National Communism: A Challenging History." Journal of Contemporary Central and Eastern Europe 22 (1): 27-48. 
Palko, Olena. 2016. "Between Two Powers: The Soviet Ukrainian Writer Mykola Khvyl'ovyi." Jahbücher für Geschichte Osteuropas 64 (4): 575-598.

Pauly, Matthew D. 2014. Breaking the Tongue: Language, Education, and Power in Soviet Ukraine, 1923-1934. Toronto: University of Toronto Press.

Rosenthal, Bernice Glatzer. 2002. New Myth, New World: From Nietzsche to Stalinism. University Park: The Pennsylvania State University Press.

Rossoliński-Liebe, Grzegorz. 2014. Stepan Bandera: The Life and Afterlife of a Ukrainian Nationalist: Fascism, Genocide, and Cult. Stuttgart: Ibidem Press.

Rossoliński-Liebe, Grzegorz. 2015. The Fascist Kernel of Ukrainian Genocidal Nationalism. Pittsburgh, PA: University of Pittsburgh Press.

Rudling, Per Anders. 2011. The OUN, the UPA, and the Holocaust: A Study in the Manufacturing of Historical Myths. Pittsburgh, PA: University of Pittsburgh Press.

Rudling, Per Anders. 2012. "Anti-Semitism and the Extreme Right in Contemporary Ukraine." In Mapping the Extreme Right in Contemporary Europe: From Local to Transnational, edited by Andrea Mammone, Emmanuel Godin, and Brian Jenkins, 189-205 . London and New York: Routledge.

Rudling, Per Anders. 2014. The Rise and Fall of Belarusian Nationalism, 1906-1931. Pittsburgh, PA: University of Pittsburgh Press.

Shapoval, Yuri, and Marta D Olnyk. 2011-2014. "Fatal Ambivalence: The GPU Case Dossier on Mykola Khvyl'ovyi." Harvard Ukrainian Studies 32 (22), Part 2. ZhNYVA: Essays Presented in Honor of George G. Grabowicz on his Seventieth Birthday: 637-664.

Shkandrij, Myroslav. 2001. Russia and Ukraine: Literature and the Discourse of Empire from Napoleonic to Postcolonial Times. Montreal: McGill-Queens University Press.

Shkandrij, Myroslav. 2015. Ukrainian Nationalism: Politics, Ideology and Literature. New Haven, CT: Yale University Press.

Shkrandrij, Myroslav. 2020. Revolutionary Ukraine, 1917-2017: History's Flashpoints and Today's Memory Wars. New York: Routledge.

Snyder, Timothy. 2005. Sketches from a Secret War: A Polish Artist's Mission to Liberate Soviet Ukraine. New Haven and London: Yale University Press.

Velychenko, Stephen. 2015. Painting Imperialism and Nationalism Red: The Ukrainian Marxist Critique of Russian Communist Rule in Ukraine, 1918-1925. Toronto: University of Toronto Press.

В’ятрович, Володимир. 2011. Друга польсько-украӥнська війна. 1942-1947. Київ: КиєвоМогилянська академія.

Донцов, Дмитро. 1944. Дух нашої давнин. Prague: Видавнитство Юрія Тищенка.

Донцов, Дмитро. 1926с. “Крок вперед (До “літературного’ спору).” Літературно-Науковий Вістник 91 (10): 167-183.

Донцов, Дмитро. 1921. Підстави нашої політики. Vienna: Донцових.

Донцов, Дмитро. 1923а. “Криза української літератури.” Літературно-Науковий Вістник 79 (4): 351-370. 
Донцов, Дмитро. 1923b. “Чи ми фашисти?” Заграва 7: 97-102.

Донцов, Дмитро. 1925. “Українсько-совєтські псевдоморфози.” Літературно-Науковий Вістник 88 (12): 321-336.

Донцов, Дмитро. 1926а. Націоналізм. Львів: Нове Життя.

Донцов, Дмитро. 1926b. “До старого спору.” Літературно-Науковий Вістник 89 (4): $355-369$.

Донцов, Дмитро. 1928. “Невільники доктрини. (Характеристика чільних письменників Радянської України).” Літературно-Науковий Вістник 97 (9): 69-87.

Донцов, Дмитро. 1933. “Микола Хвильовий.” вістник 7/8: 591-601. (Republished in 1973. Сучасність. 5: 75-94).

Донцов, Дмитро. 1938. “Шляхом велетнів.” Вістник 10: 734-739.

Зайцев, Олександр. 2014. Українсъкий інтегральний націоналізм 1920-1930-х років: Нариси інтелектуальної історії. Київ: Критика.

Зайцев, Олександр. 2019. Націоналісту добі фашизму. Львівський період Дмитра Донцова: 1922-1939 роки. Начерк інтелектуальної біограбї. Київ: Критика.

Зеров, Микола. 1990. “Ad fontes.” In Твори в двох томах. т. 2. Київ: Дніпро: 568-588.

Квіт, Сергій. 2013. Дмитро Донцов: ідеологічний портрет. Львів: Галицька видавнича спілка.

Липинський, Вячеслав. 1926. Листи до Братів-Хліборобів: про ідею і організацію украйнського монархізму.Vienna: Carl Herrmann.

Мартинець, Володимир. 1949. Від УвО до ОУН: спогади та матеріяли до передісторіӥ та історї украӥнського організованого націоналізму. Winnipeg, Ukrainian National Federation.

Мірчук, Петро. 1968. Нарис історӥ Організациї Украӥнських Націоналістів, т. 1. Мюнхен: Українське Видавництво.

Міхновський, Микола. 1902. Самостійна Украӥна. Львів, Вядає Е. Косевич.

Рахманний, Роман. 1984. Дмитро Донцов і Микола Хвильовий 1923-1933. London: Українська Видавнича Спілка.

Сосновський, Михайло. 1974. Дмитро Донцов. Політичний портрет. 3 історї̈ розвитку ідеологї̈ украӥнського націоналізму. Нью-Йорк; Торонто: Trident International, Inc.

Хвильовий, Микола. 1925. Камо грядеши: памфлети. Харків: Книгоспілка.

Хвильовий, Микола. 1978. Твори у 5-ти томах. т. 4. Нью-Йорк; Балтімор; Торонто: Укр. вид-во «Смолоскип» ім. В. Симоненка.

Чугуєнко, Михайло. 1996. “Ідеі консервативної революції в украінській суспільнополітичній думці: Д. Донцов і М. Хвильовий.” In Доповіді та повідомлення 3-го міжнар. Конгресу українців "Політологія, етнологія, соціологія, edited by О. Петровський, 305310. Харків: Око. 